\title{
Climate justice in the endgame for two degrees
}

Article

Accepted Version

McKinnon, C. (2019) Climate justice in the endgame for two degrees. The British Journal of Politics and International Relations, 21 (2). pp. 279-286. ISSN 1369-1481 doi: https://doi.org/10.1177/1369148119827259 Available at https://centaur.reading.ac.uk/80586/

It is advisable to refer to the publisher's version if you intend to cite from the work. See Guidance on citing.

To link to this article DOI: http://dx.doi.org/10.1177/1369148119827259

Publisher: SAGE Publications

All outputs in CentAUR are protected by Intellectual Property Rights law, including copyright law. Copyright and IPR is retained by the creators or other copyright holders. Terms and conditions for use of this material are defined in the End User Agreement.

\section{www.reading.ac.uk/centaur}

\section{CentAUR}

Central Archive at the University of Reading

Reading's research outputs online 


\title{
Climate justice in the endgame for 2 degrees
}

\author{
Catriona McKinnon \\ Professor of Political Theory \\ Director, Centre for Climate and Justice \\ University of Reading \\ c.mckinnon@reading.ac.uk
}

Key words: climate justice; subsistence emissions; environmental pragmatism; climate policy; climate engineering; moral anger. 


\section{Climate justice in the endgame for 2 degrees}

One of the most striking features of Henry Shue's work on climate justice is its moral anger. Shue calls out inadequate governmental action on climate change since 1992 as shameful and pathetic. He describes most countries' Nationally Determined Contributions (NDCs) under the Paris Agreement as 'paltry', 'pitiful' and 'farcical'. Those in the Trump administration are called 'environmental vandals'. For many people, the righteous anger that simmers beneath the surface of his words is the morally and emotionally appropriate response to the delays in political action on climate change that have left us with just eighteen years until the carbon budget for two degrees is depleted. ${ }^{1}$ Shue's moral anger is crystallised in his denunciation of climate policies that depend on some people sacrificing subsistence in order that others can enjoy luxuries. The earliest versions of this critical line focus on emissions created by subsistence in a global economy locked in to fossil fuels. Later versions - including this Breakthrough Article - expand the call for protection of the means to subsistence as a non-negotiable feature of any just transition to a zero carbon global economy. As Shue puts it, 'the politically crucial question of the fair sharing of burdens cannot be evaded and will not be forgotten' (p. xxx).

\footnotetext{
${ }^{1}$ 'Carbon Countdown Clock', The Guardian. Available at https://goo.gl/AWzoGX. Accessed 6
} March 2018. 
Here, I offer two unconnected reflections. The first relates to the general importance of calling out injustice in climate policymaking, of which Shue's work is a paragon. The second suggests ways in which to extend the work that can be done by the moral imperative that undergirds Shue's original commitment to subsistence emissions, and now his support for the Climate Equity Reference Framework (CERF) in the transition to a zero carbon global economy.

\section{Calling out unjust climate policy}

Shue's calling out of egregious injustices in political action on climate change has been resisted. Some people have denied that the climate wrongdoers Shue identifies (most frequently, the United States) are in fact at fault (Posner and Weisbach, 2010). Others have claimed that taking feasibility seriously puts most of the injustices identified by Shue beyond the scope of climate policymaking (Gardiner and Weisbach, 2016); that most ethical judgements underdetermine decisions on climate policy (Hulme, 2009; Light and Taraska, 2016); or that economic valuation must be used to capture everything that matters in climate policymaking, including the ethical stakes (Tol, 2008). ${ }^{2}$

I shall focus on a different path of resistance, which takes seriously the requirement that climate policy must serve the ends of climate justice. This is the 'pragmatist' view that if climate policy is to be an effective instrument of climate justice, the ethical demands of the ideals of climate justice must not be at too great a distance from the actual processes and

\footnotetext{
${ }^{2}$ For critique see Spash 2017.
} 
parameters of climate policymaking (Light, 2011). For example, ethically infused thinking about climate justice could miss the policy mark if the standards it applies to policy proposals are too abstract (for example, 'the dignity of all must be respected') or too rhetorical (for example, 'let us heal the Earth'). It is obvious that a good way for moral arguments and ethical values to make a difference to political action on climate change is to engage with the details of climate policies; ideally, as these policies are being decided or implemented. But we should not ignore a serious risk in this sort of engagement; viz. that immersion in policy analysis can become nothing but policy analysis. Disappearing down this rabbit hole risks letting the policy intervention drift loose from its moral anchor. When this happens it can be hard to tell whether a pragmatist policy intervention in the name of climate justice hits its mark because the intervention has been so leached of freestanding ethical commitments that its original purpose is obscured.

In reality, then, any climate ethicist aspiring to engage with policy to make it serve climate justice can miss the mark in two ways. Too distant from policy, and the ethics become irrelevant; too close to policy, and the ethics disappear. Instead, the ideal should be to bring independently justified ethical principles into policy debates in ways that make the connection between the principles and the policy recommendation ethically readable both to those involved in policy discourse, and to people beyond these narrow circles. A policy is ethically readable when the ways in which it promotes, or is consistent with, an ethical principle is (or can be made) clear to publics whose interests are protected by the principle. For climate policy, the relevant publics encompass the whole of humanity; in particular, those portions of humanity most vulnerable to ethically unacceptable climate policy, viz. the 
world's poorest people, including those not yet born. ${ }^{3}$ Ethical readability matters for reasons of accountability: people affected by a policy should be able to assess how well that policy protects their interests. Arguably, ethical readability also matters for its own sake: policy ought to be constrained by at least some ethical principles. The policies we get by taking ethical readability seriously will depend on the ethical principles that apply in the case.

Here, I want to focus on a different reason why ethical readability matters. This is that leaching climate policy of ethical content by too much well-intentioned policy wonkeryand thereby failing standards of ethical readability - could do damage to people most vulnerable to climate change, for the following reasons. We know that moral convictions about climate change can be motivating and likely to stimulate action in the right circumstances (Markowitz and Shariff 2012). Circumstances that are not right include those in which people with moral convictions about climate change lack efficacy with respect to bringing about the outcomes they value. When people repeatedly fail to influence political decision making in ways that are informed by what they care about, their inefficacy can curdle into apathy or defensiveness (Täuber et al., 2015). If what people care about is justice in climate policy, this is bad news insofar as it dilutes pressure from below on politicians to craft just climate policy.

\footnotetext{
${ }^{3}$ There are hard questions about how to ensure the interests of future people are respected in climate policymaking, and politics. For creative answers see (González-Ricoy and
} Gosseries, 2016). 
We should be worried about this given the following facts. Climate impacts will cause most damage to people in the world's poorest countries. Rich countries have the greatest potential to minimise these unjust damages because their historical responsibility for climate change has endowed them with a capacity to slash emissions (as required by climate justice) that is not matched by equivalent capacities in poorer countries. The historical emissions of the richest countries have enabled them to develop in ways that have made them resilient to the climate change that now makes carbon-intensive development by the poorest countries of the world impossible if we are to achieve the highest ambitions of the Paris Agreement. Furthermore, these countries also bear most responsibility as a result of their present emissions. Rich, climate resilient countries have more direct control over the flow of emissions that are on course to deplete the carbon budget, and can be asked to bear enormous cuts to these emissions without significant ethical loss, given that a large proportion are luxury emissions.

Taking these facts together, the action on climate change of the world's richest and most climate resilient countries has greater potential to minimise climate injustice than that of the world's poorest and least resilient countries: these countries can prevent (or at least, slow down) depletion of the carbon budget in ways demanded by climate justice, and have a duty to lead on this. ${ }^{4}$ If citizens of the richest and most stable countries in the world

\footnotetext{
${ }^{4}$ As Shue points out, these countries in fact have a duty to do far more than this. Given the failure of past political action to significantly reduce emissions, cuts must be accompanied by technology and resource transfer to enable net zero without violating the basic rights of people at risk of losing land and access to water through, for example, BECCS (Shue, 2017).
} 
become apathetic and defensive about just climate policy, they are far less likely to exercise whatever influence they have - for example, through NGOs - on climate policymakers at national and global levels to avoid unjust climate policy.

Here is where the ethical readability of climate policy matters for climate justice. In the face of climate policy deliberations leached of explicit ethical commitments, it could easily appear to people committed to climate justice that a major route to avoiding climate injustice has been shut down. The protestations of well-intentioned policy wonks that the train is still on track, despite appearances to the contrary, risk leaving ethically motivated people enervated. For such people, the values of justice they cleave to must be recognisable in climate policy that (at least) avoids injustice. If the climate policy of the world's richest and most climate resilient countries remains egregiously unjust, despite the best efforts of climate justice champions in those countries, a wellspring of ethical criticism of these policies could run dry. However dim they are now, if the lights go out on climate justice in public discourse about climate change, the prospects for policy designed to minimise climate injustice will become even shakier, given how enormously tempting it is for politicians to make self-serving decisions and dress them up as pragmatic climate action (Gardiner, 2011)(Gardiner, 2013). ${ }^{5}$ By insisting on climate policies that make their climate justice commitments readable to people who care about climate justice, we will increase the likelihood of achieving more climate justice by bolstering the efficacy of people disposed

\footnotetext{
${ }^{5}$ Of course, the most obvious reason why climate policy ought to promote climate justice is that policymakers - like everyone else - have duties to promote justice.
} 
to put the right kind of pressure on political leaders. ${ }^{6}$

I have argued that we must bring policy discourse closer to whatever ethically informed public discourse exists. This means encouraging policy discussions explicitly to address the justice and ethics dimensions of the policies in ways that make the justice outcomes of the policies readable as such to people who are committed to climate justice. Policy-engaged work, such as that by Shue on subsistence emissions, is vital for the generation of these discussions. This type of ethically engaged policy discourse would not only avoid enervating people already committed to climate justice, it could also spread these commitments. One good way to bring outsiders into a normative debate - so that they become motivated by the ethical principles around which the praise and blame practices of any society are oriented - is for political leaders to unambiguously and clearly govern in ways that promote values around which a sense of belonging can coalesce, and from which ethical convictions can be strengthened (Täuber et al. 2015, 460-1). ${ }^{7}$ Rather than seeking pragmatic routes to climate policies that risk draining away climate justice altogether, policymakers could be crafting climate policies so as to build and strengthen values friendly to climate justice in the communities they serve. The steps from this process to legislative and policy change to promote a robust vision of climate justice might then be taken more quickly.

Henry Shue's insistence that basic rights to subsistence - the rights of people we are moving

\footnotetext{
${ }^{6}$ An additional benefit of ethical readability is that is keeps alive hope for climate justice. See (McKinnon, 2014).

${ }^{7}$ See (Caney, 2012).
} 
with together through time, and the rights of people whose world will be what we make it provides fuel for these processes. His earliest presentations of the division of the remaining carbon budget as a zero sum game between those whose lives depend on subsistence emissions, and those whose pleasures require continued luxury emissions, has a force that does not depend on accepting any high moral theory. Now that remaining within the budget looks impossible with emissions reductions alone, making NETs and a massive upscaling of renewables necessary for us to avoid catastrophic warming, the basic right to subsistence retains its force.

\section{Climate engineering and the constraints of justice}

In his Breakthrough Article, Shue shows the clear policy implications of protecting the basic right to subsistence in our present endgame for transition to a zero carbon global economy. First, he shows how the Climate Equity Reference Framework (CERF) for assessing NDCs under the Paris Agreement supports subsistence emissions for development for countries below a morally defensible threshold. At the same time, CERF offers a two pronged construal of the mitigation duties of rich, high emitting countries: their luxury emissions must be reduced and they must finance renewables in countries below the development threshold, until zero carbon is achieved. ${ }^{8}$ And second, he identifies the threats to basic rights to subsistence that are created if NDCs fail to conform to CERF, which could make increasingly heavy reliance on large scale carbon dioxide removal (CDR) a serious policy

\footnotetext{
${ }^{8}$ I do not mean to suggest here that emissions reductions and scaling up of renewables ala CERF is sufficient for zero carbon.
} 
option. As Shue argues, the CDR technology assumed by most IPCC scenarios in which warming is limited to two degrees or less - bioenergy combined with carbon capture and storage (BECCS) - requires land and water usage that will compete with what is needed to satisfy the subsistence rights of the world's poorest people. Given the sorry history of how the world's highest emitting and richest countries have prioritised their luxury emissions over the subsistence emissions of the most vulnerable members of the human community, we have reason to be seriously worried about this pattern repeating in a climate engineered world of BECCS (Shue, 2017).

In fact, I think the threats to basic rights in the endgame for limiting warming to two degrees are even greater than shown by Shue. CDR is not the only type of climate engineering. In addition, solar radiation management (SRM) is being discussed as a way to buy additional time for emissions reductions. Although CDR and SRM are both forms of climate engineering insofar as they involve 'deliberate large-scale manipulation of the planetary environment to counteract anthropogenic climate change' (The Royal Society 2009 , p. 1), they operate differently. Whereas CDR removes carbon dioxide from the atmosphere, SRM methods reduce warming without extracting any greenhouse gases. SRM methods deflect solar radiation away from the planet by increasing the planet's albedo through altering the reflectivity of the surface, clouds, or the atmosphere. A prominent field experiment for SRM technology is due to take place soon and the pace may pick up thereafter. ${ }^{9}$ There are signs that geoengineering is catching the attention of legislators and diplomats: the US Senate appropriations committee recently passed a spending bill that

\footnotetext{
${ }_{9}^{9}$ See https://geoengineering.environment.harvard.edu/. Accessed 8 November 2018.
} 
included funding to support geoengineering research (Nuccitelli, 2016); there have been recent US house subcommittee hearings on geoengineering; and the head of the IPCC, Hoesung Lee, has said that Panel should be examining SRM - including its governance - very seriously (Goldberg, 2016)..$^{10}$

The particular form of SRM around which most activity is happening is stratospheric aerosol injection (SAI), which proposes to deliver reflective particles (most commonly, sulphur) to the stratosphere. Prominent scientific researchers in SRM make the case for accelerated research in this area in terms of SRM as a potentially powerful, relatively cheap, and effective tool to achieve a reduction in the rate of temperature increase to buy time for mitigation (Keith, 2013; MacMartin et al., 2014). Although SRM research is in its infancy, it is not hard to imagine its allure (McMahon, 2017), especially for rich countries that declare their luxury emissions as a way of life, ${ }^{11}$ billionaire philanthropists enthusiastic about techno-fixes (Nelsen, 2017), and fossil fuel companies who see the end coming and need to feed the bottom line.

Just as with BECCS, the most sober calls for research into SRM declare commitment to protecting the world's most vulnerable people (Horton and Keith, 2016). However, a number of studies have suggested that, whether deployed uniformly across the globe, or

\footnotetext{
${ }^{10}$ See (Chhetri et al., 2018).

${ }^{11}$ Just before the start of the Earth Summit in Rio de Janeiro in 1992, President George H.W.

Bush declared: "The American way of life is not up for negotiations. Period."
} 
concentrated in a particular hemisphere, SAI could have disastrous effects on the world's poorest people. Models have suggested that SAI could disrupt Asian and African summer monsoons (Robock et al., 2008), reduce in precipitation in Africa, South America and South East Asia (Svoboda et al., 2011), increase tropical cyclone frequency (Jones et al., 2013), and cause drought in the Sahel (Haywood et al., 2013). Noting this, two leading figures in the SRM scientific research community reply that, '[i]ntroducing multiple spatial and temporal degrees of freedom [in insolation reduction] has the potential to improve how well SRM can compensate for $\mathrm{CO} 2$-induced climate change, and thus reduce concerns over the resulting regional inequalities' (Macmartin et al. 2013: 365). In other words, enabling deployment of SRM at different places on the globe, at different times, could allay the worst outcomes for the world's poorest people without diminishing the overall cooling benefits of SAI. This is, the authors suggest, a way of making more palatable the range of 'trade-offs' SAI necessitates.

We should not be reassured by this. Regional and temporal variations in SAI deployment would not remove the need for trade-offs; redolent as it is of maximising consequentialism in policy making, the language of 'trade-offs' should set ethical alarm bells ringing. From Rio onwards, rich and powerful countries responsible for climate change have without fail prioritised their luxury emissions over the subsistence emissions of poor and vulnerable countries with miniscule historical emissions. It is naïve to the point of incredulity to think that these same countries could be trusted to trade off their own luxury emissions so as to give priority to the basic subsistence rights of the world's poorest people. Introducing regional and temporal variations in SAI deployment has the potential to twist the 'moral hazard' created by SRM so as to pin the world's poorest people at the end of the spike of 
delayed emissions reductions by the rich. ${ }^{12}$

Perhaps this is not inevitable. Perhaps, with the right governance of the research and development of SRM, the ethically horrible dangers of potential deployment could be neutralised. This can only happen if we strenuously align policy and governance conversations with demanding ideals of climate justice, with Shue's work on the moral primacy of subsistence over luxury at front of this mix.

My comments here have been supportive of Shue's approach: there is no point in posturing otherwise when the stakes are so high. Shue was one of the first political philosophers to present the challenges of climate change as ethical problems. His moral clarity of vision and analytical power have combined to identify ethically acceptable, and morally heinous, climate policies, in ways that speak to people across the spectrums of theory and practice, and from many different disciplinary perspectives. Very few political philosophers have achieved this. If we aim to get through this century's climate crisis with any semblance of justice in our means and ends, we need Shue's body of work as our guide.

${ }^{12}$ The terminology of 'moral hazard' originates in debates about insurance. The central thought is that when insurance is in place to cover an unwelcome outcome, people are less likely to avoid the behaviour that increases the likelihood of the outcome. Applied to geoengineering, the central worry is deployment - or even just research into the technology - could undermine mitigation through reductions in greenhouse gas emissions. See Hale 2012. 


\section{Acknowledgements}

I am grateful to Alex McLaughlin and anonymous referees for this journal for their useful written comments. I am also grateful from feedback from Elizabeth Cripps, Giovanna Di Chiro, Robert Falkner, David Schlosberg, Henry Shue, and others present at a workshop in July 2018 held at the Reading Centre for Climate and Justice, at which the papers in this special issue were discussed.

\section{References}

Caney S (2012) Addressing Poverty and Climate Change: The Varieties of Social Engagement. Ethics and International Affairs 26(2): 191-216. DOI: 10.1017/S0892679412000299.

Chhetri N, Chong D, Conca K, et al. (2018) Governing Solar Radiation Management.

Washington, D.C. DOI: https://doi.org/10.17606/M6SM17.

Gardiner SM (2011) A perfect moral storm : the ethical tragedy of climate change. Oxford University Press.

Gardiner SM and Weisbach DA (2016) Debating Climate Ethics. Oxford: Oxford University Press. DOI: 10.1093/acprof:oso/9780199996476.001.0001.

Goldberg S (2016) UN climate science chief: it's not too late to avoid dangerous temperature rise | Environment | The Guardian.

González-Ricoy I and Gosseries A (2016) Institutions For Future Generations. Oxford: Oxford University Press. DOI: 10.1093/acprof:oso/9780198746959.001.0001.

Hale B (2012) Geoengineering and Moral Hazards. Engineering the Climate: The Ethics of Solar Radiation Management.

Haywood JM, Jones A, Bellouin N, et al. (2013) Asymmetric forcing from stratospheric 
aerosols impacts Sahelian rainfall. Nature Climate Change 3. DOI:

10.1038/NCLIMATE1857.

Horton J and Keith D (2016) Solar Geoengineering and Obligations to the Global Poor. In:

Preston CJ (ed.) Climate Justice and Geoengineering: Ethics and Policy in the

Atmospheric Anthropocene. Rowman and Littlefield International, pp. 79-92.

Hulme M (2009) Why we disagree about climate change : understanding controversy, inaction and opportunity. Cambridge University Press.

Jones A, Haywood JM, Alterskjaer K, et al. (2013) The impact of abrupt suspension of solar radiation management (termination effect) in experiment G2 of the Geoengineering Model Intercomparison Project (GeoMIP). Journal of Geophysical Research:

Atmospheres 118(17): 9743-9752. DOI: 10.1002/jgrd.50762.

Keith DW (2013) A case for climate engineering. Boston: MIT Press.

Light A (2011) Climate Ethics for Climate Action. Environmental Ethics: What Really Matters? What Really Works?

Light A and Taraska G (2016) A Responsible Path. In: Heyward C and Roser D (eds) Climate Justice in a Non-Ideal World. Oxford University Press.

Macmartin DG, Keith DW, Kravitz B, et al. (2013) Management of trade-offs in geoengineering through optimal choice of non-uniform radiative forcing. DOI:

10.1038/NCLIMATE1722.

MacMartin DG, Caldeira K and Keith DW (2014) Solar geoengineering to limit the rate of temperature change. Philosophical Transactions of the Royal Society A 372: 20140134. DOI: 10.1098/rsta.2014.0134.

Markowitz EM and Shariff AF (2012) Climate Change and Moral Judgement. Nature Climate Change 2. DOI: 10.1038/NCLIMATE1378. 
McKinnon C (2014) Climate change: Against despair. Ethics and the Environment 19(1): 3148. DOI: 10.1353/een.2014.0000.

McMahon J (2017) As humans fumble climate challenge, interest grows in geoengineering. Available at: https://www.forbes.com/sites/jeffmcmahon/2017/09/24/interest-risesin-geoengineering-as-humans-fail-to-mitigate-climate-change/\#1d6904226472 (accessed 28 March 2018).

Nelsen A (2017) US scientists launch world's biggest solar geoengineering study. The Guardian, March.

Nuccitelli D (2016) Scientists Debate Experimenting With Climate Hacking to Prevent Catastrophe. The Guardian, June.

Posner EA and Weisbach DA (2010) Climate change justice. Princeton: Princeton University Press.

Robock A, Oman L and Stenchikov GL (2008) Regional climate responses to geoengineering with tropical and Arctic SO2 injections. Journal of Geophysical Research 113(D16). Wiley-Blackwell: D16101. DOI: 10.1029/2008JD010050.

Shue H (2017) Climate dreaming: negative emissions, risk transfer, and irreversibility. Journal of Human Rights and the Environment 8(2). Edward Elgar Publishing Ltd: 203216. DOI: 10.4337/jhre.2017.02.02.

Spash C (2017) The New Environmental Pragmatists, Pluralism and Sustainability. Environmental Values 18(3): 253-256.

Svoboda T, Keller K, Goes M, et al. (2011) Sulfate Aerosol Geoengineering: The Question of Justice. Public Affairs Quarterly 25(3): 157-180.

Täuber S, van Zomeren M and Kutlaca M (2015) Should the moral core of climate issues be emphasized or downplayed in public discourse? Three ways to successfully manage the 
double-edged sword of moral communication. Climatic Change 130(3): 453-464. DOI: $10.1007 / \mathrm{s} 10584-014-1200-6$.

The Royal Society (2009) Geoengineering the climate: science, governance and uncertainty. Clean Technologies and Environmental Policy. DOI: 10.1007/s10098-010-0287-3. Tol RSJ (2008) Why Worry About Climate Change? A Research Agenda. Environmental Values 17(4): 437-470. DOI: 10.3197/096327108X368485. 